\title{
Morphometric Characteristics, Shapes and Provenance of Holocene Pebbles from the Sava River Gravels (Zagreb, Croatia)
}

\author{
Uroš Barudžija ${ }^{1, * \mathbb{C}}$, Josipa Velić ${ }^{1}$, Tomislav Malvić ${ }^{1, * \mathbb{C}}$, Neven Trenc $^{2}$ and \\ Nikolina Matovinović Božinović ${ }^{1}$ \\ 1 Faculty of Mining, Geology and Petroleum Engineering, University of Zagreb, 10000 Zagreb, Croatia; \\ josipa.velic@rgn.unizg.hr (J.V.); nikolina.matovinovic@gmail.com (N.M.B.) \\ 2 Croatian Agency for Environment and Nature, 10000 Zagreb, Croatia; neven.trenc@gmail.com \\ * Correspondence: uros.barudzija@rgn.unizg.hr (U.B.); tomislav.malvic@rgn.unizg.hr (T.M.); \\ Tel.: +385-1-5535-791 (U.B.)
}

Received: 30 January 2020; Accepted: 26 February 2020; Published: 29 February 2020

\begin{abstract}
Morphometric analysis of Holocene pebbles from Sava River gravel in NW Croatia revealed shape distributions as observed along a $30 \mathrm{~km}$ long watercourse. Limestones, dolomites, and sandstones were identified as the major $(>4 \%)$ and effusive magmatics in this alluvial aquifer system in Zagreb, with cherts and tuffs as minor pebble lithologies (up to $4 \%$ ). Their distributions mainly indicate distant Alpine provenance for carbonate pebbles (limestone and dolomite) and local input for sandstones and minor lithotypes, laterally from the Samoborska Gora and Medvednica mountain. Carbonates are predominantly disc- and sphere-shaped, implying distant sources. Scattered distributions of pebble shapes (sphere, disc, blade, and rod) for sandstones and minor lithotypes possibly indicate multiple sources, some of them probably local. The tentatively interpreted "original sedimentary environments" for the main pebble lithotypes (calculated from their flatness ratios) possibly indicate that they are predominantly lake beach pebbles, followed by moraine and riverbed pebbles. However, these results should be strongly questioned.
\end{abstract}

Keywords: quaternary; Holocene; alluvial sediments; Sava River; gravels; morphometry; Zagreb; Croatia

\section{Introduction}

Morphometric research is often conducted to determine the weathering, transport, provenance, and depositional mechanisms/processes of gravel. Non-lithified alluvial sediments deposited in Quaternary braided or meandering river systems, such as the Holocene sediments in Sava River alluvial terraces near the city of Zagreb (Croatia), are especially suitable for such studies.

Holocene deposits, which make up the youngest parts of the Zagreb alluvial aquifer system [1-7], were used in a case study that analysed the morphometric and lithological characteristics of gravel pebbles. It aimed to describe transport and depositional mechanisms, as well as the potential of the applied method to analyse complex deposition and transport history. The research also included petrographic analysis and description of pebbles, as well as interpretation of provenance and paleotransport.

The contribution of eroded material brought in by lateral streams from the nearby Samoborska Gora, Marijagorička brda Hills, and Medvednica mountain was compared to material carried from the more upstream Alpine area, transported by the Sava River. The research was conducted along a $30 \mathrm{~km}$ long traverse following the Sava River. The aim of this paper is to present and evaluate the results of that study. 


\section{Geological Settings}

The Sava River originates in Slovenia at the foot of the Southern Calcareous Alps. It flows through Slovenia, enters Croatia approximately $15 \mathrm{~km}$ west of Zagreb (Figure 1), and flows further eastward along the border between Croatia, Bosnia, and Herzegovina. After its approximate $950 \mathrm{~km}$ run, it finally enters the Danube River in Serbia, near Belgrade. As Sava River flows through a higher terrain in Slovenia, its riverbed becomes shallow, and its deposits are predominantly coarse (mainly gravel), resembling braided river transport and depositional mechanisms. Geomorphological transitions cause a change in riverbed characteristics. West of Zagreb and downstream towards the east, the river morphology transitions again, now taking a predominantly meandering form. The flow of watercourses (blue streamline and modern lakes/gravel pits in Figure 1) have been highly regulated and embanked since the beginning of the 20th century and after the major flooding of the city of Zagreb in 1964. Currently, deposits found in the Sava River system are primarily used in gravel pits and foundation works for buildings and infrastructure.

According to Geology of Zagreb and Ivanić-Grad Sheets [8,9] and accompanying texts for respective basic geological maps of the area [10,11], Quaternary deposits in Zagreb alluvial plain can be distinguished as those of Pleistocene and Holocene ages, forming three lithostratigraphic units: (1) the oldest unit (determined as of Pliocene to Lower Pleistocene age), consisting mainly of gravels, sands, and clays; (2) the middle unit (of Middle to Upper Pleistocene age), consisting of loess deposits and fine clayey silts with some interlayers of sands and gravels and, occasionally, peat and swamp sediments; and (3) the youngest unit, consisting of alluvial deposits, deposited within the last $10 \mathrm{Ka}$ since the Sava River was mostly formed as a watercourse.

The youngest deposits are mainly in the form of gravels, sands, and subordinately silty clays. The pebbles in gravel deposits are predominantly carbonates (limestones and dolomites), sandstones, effusive magmatics, cherts, and tuffs. The surrounding hills are built of various Palaeozoic, Mesozoic, and Cenozoic rocks-magmatic, metamorphic, and sedimentary (Figure 1), which can be compared with gravel pebbles. These results are also well documented by several studies [11-17].

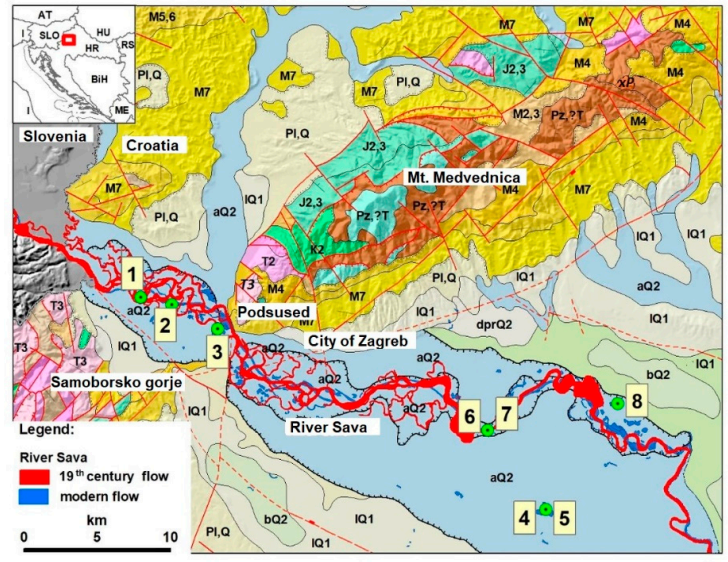

Figure 1. Geographical location and map of the study area. Sava River watercourses: non-regulated (red) and regulated (blue), sampling locations (green dots: 1-8): 1-Samobor; 2-Savršćak; 3-Orešje; 4-Novo Čiče1; 5-Novo Čiče 2; 6-Novi Petruševec 1; 7-Novi Petruševec 2; 8-Ivanja Reka. Modified from [18]. Legend for geology, from [19]: xP-Permian (magmatics: quartz diorites, granodiorites); Pz?T-P-Palaeozoic to Triassic (parametamorphites); T2-Middle Triassic (carbonates, clastic, and pyroclastic deposits); T3-Norian to Rhaetian (dolomites); J2,3-Middle to Upper Jurassic (ophiolites); K2-Upper Cretaceous (carbonate clastics and "Scaglia" limestones); M2,3-Ottnangian to Carpathian (clastics, carbonates with clastics); M4-Badenian (Lithothamnium limestones and similar rocks); M5,6-Sarmatian to Pannonian (carbonate clastics); M7-Pontian (clastics and coal); Pl,Q-Plio-Quaternary (clastic deposits); IQ1—Pleistocene (loess sediments); dprQ2: Holocene (diluvial and proluvial sediments); aQ2—Holocene (fluvial deposits); bQ1—Holocene (pond deposits). 
Later researchers defined these deposits more precisely. For Middle Pleistocene gravels in the area west of Zagreb, it was determined that the predominant sandstone pebbles originated from a nearby source area, i.e., from Medvednica, Samoborska Gora, and Marijagorička brda, and for the overlying alluvial Sava gravels, a predominantly carbonate lithology of the Alpine provenance was determined [20]. Four Pleistocene-Holocene units were precisely distinguished [21]: (I) Lower Pleistocene loess-like deposits, with some paleosoil characteristics; (II) Middle Pleistocene sandy gravels determined as lake deposits, with the transition into sandstones and pelitic sediments (even to loess with paleosoils); (III) Upper Pleistocene loess, followed by swamp and lake deposits; and (IV) Holocene alluvial gravels. These deposits were later well correlated with the deposits investigated towards east [22], showing mainly quartz/quartzite/chert pebbles assemblage of Pleistocene gravels, and a predominantly carbonate pebble assemblage of Holocene sandy gravels.

\section{Materials and Methods}

To ensure quality and reliability of the obtained results, the following field and laboratory procedure was conducted. In the field, representative locations for sampling of the Holocene gravel beds were chosen, starting from the west and downstream to the east of the city of Zagreb (green dots in Figure 1). Sampling sites (Table 1) were located at nearby gravel pits, at the banks of the Sava River, and at riverbed gravel bars (Figure 2a,b).

Table 1. Investigated locations, GPS coordinates, and sampling sites.

\begin{tabular}{cccc}
\hline Location & GPS-x & GPS-y & Sampling Site \\
\hline 1 Samobor & 5560624 & 5076992 & Riverbank \\
2 Savršćak & 5558828 & 5077405 & Gravel pit bank \\
3 Orešje & 5563603 & 5075142 & Gravel pit bank \\
4 Novo Čiče 1 & 5586316 & 5063596 & Gravel pit bank \\
5 Novo Čiče 2 & 5586316 & 5063596 & Gravel pit bank \\
6 Novi Petruševec 1 & 5582269 & 6068848 & Riverbed bar \\
7 Novi Petruševec 2 & 5582284 & 5068884 & Riverbank \\
8 Ivanja Reka & 5590634 & 5070751 & Gravel pit bank \\
\hline
\end{tabular}

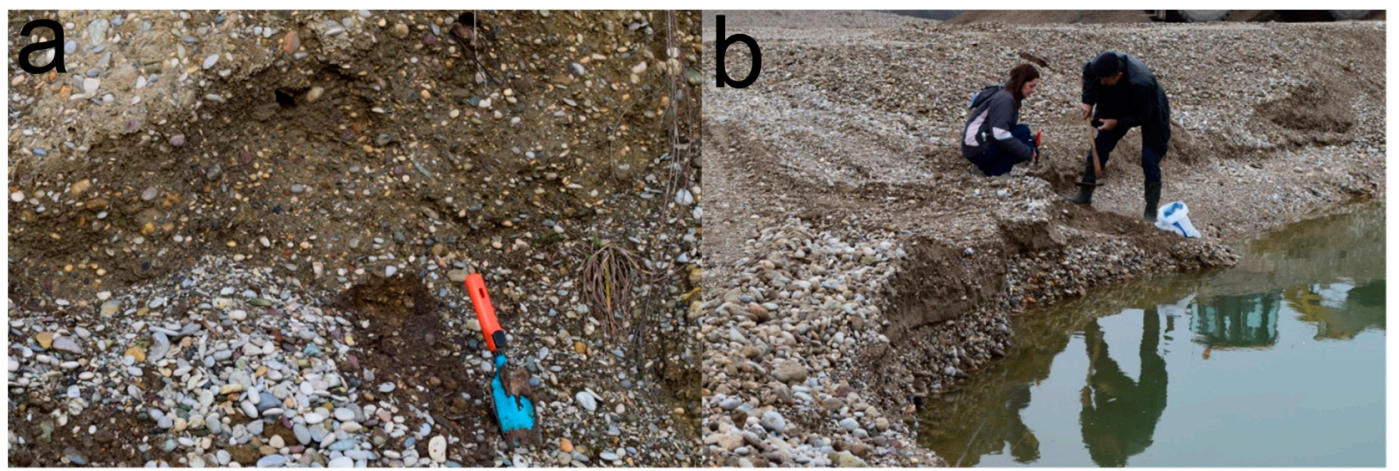

Figure 2. Sampling at gravel pit banks: (a) Ivanja Reka; (b) Savršćak.

Samples were taken from within the single visible undisturbed bedforms/layers as bulk samples, i.e., they are not discriminately taken according to the size of the clasts.

In the laboratory, a total of 8 bulk samples were dried on air and sieved on 6, 4, and $2 \mathrm{~mm}$ sieves. Statistical representative sets of 300 pebbles [23-26] of various sizes were taken from the largest separated fractions $(>6 \mathrm{~mm}$ ) of each sample, making a total set of 2400 pebbles prepared. Macroscopic lithological determinations were made, and pebbles are grouped according to determined lithotypes (Figure 3a-h). 


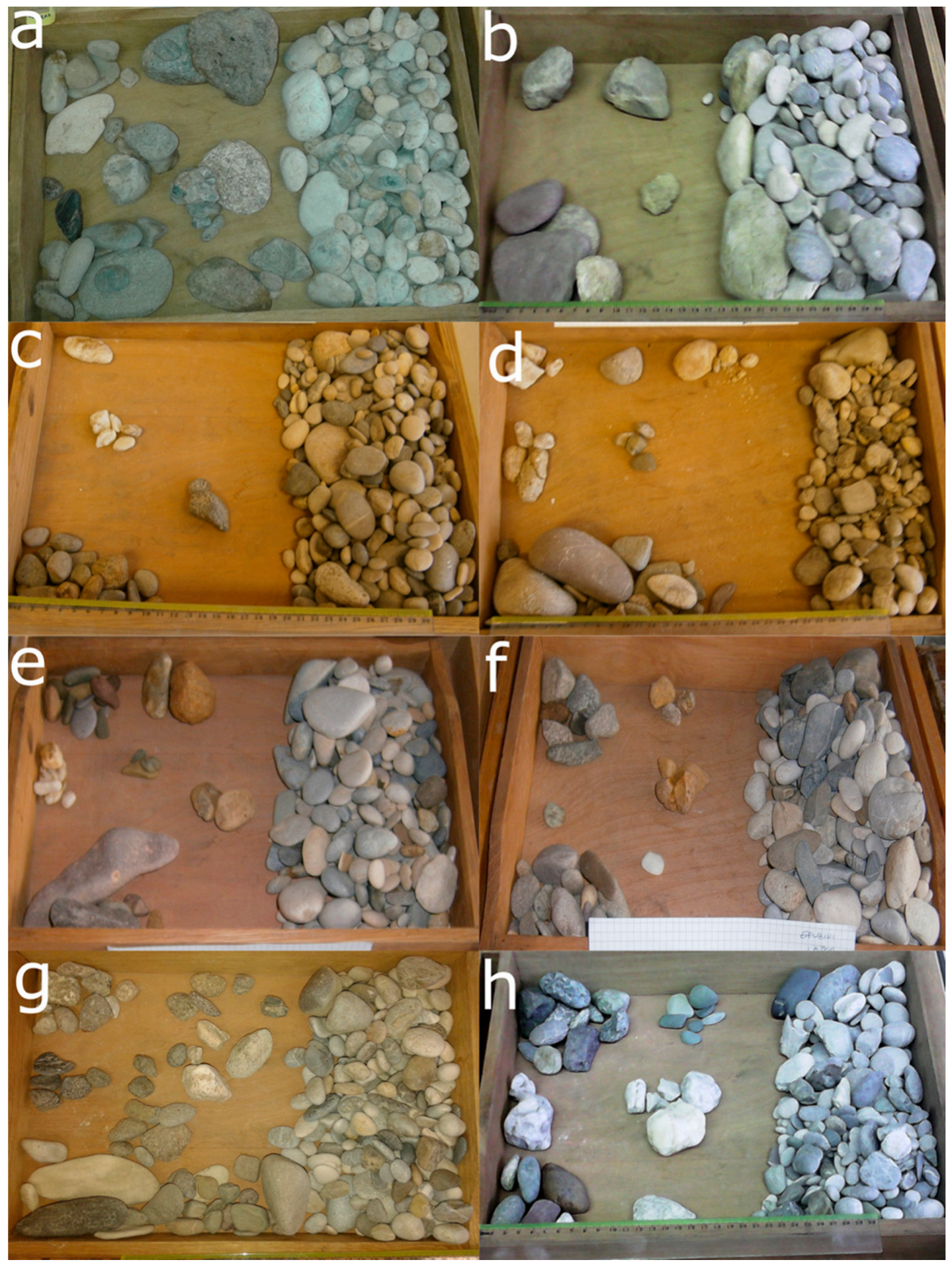

Figure 3. Analysed pebbles grouped into lithotypes, at locations: (a)—Samobor; (b)—Savršćak; (c)—Orešje; (d)-Novo Čiče1; (e)-Novo Čiče2; (f)-Novi Petruševec1; (g)-Novi Petruševec2; (h) -Ivanja Reka. The division on the yellow scale, visible on the lower width of panels b, c, d, and $h$, is in centimetres.

Additionally, thin sections from the most common pebbles at one representative site (Samobor location) were analysed by polarising microscope in order to support the macroscopic determinations of the lithotypes. Micropetrographic analysis confirmed the major lithotypes (Figure 4a-f). 


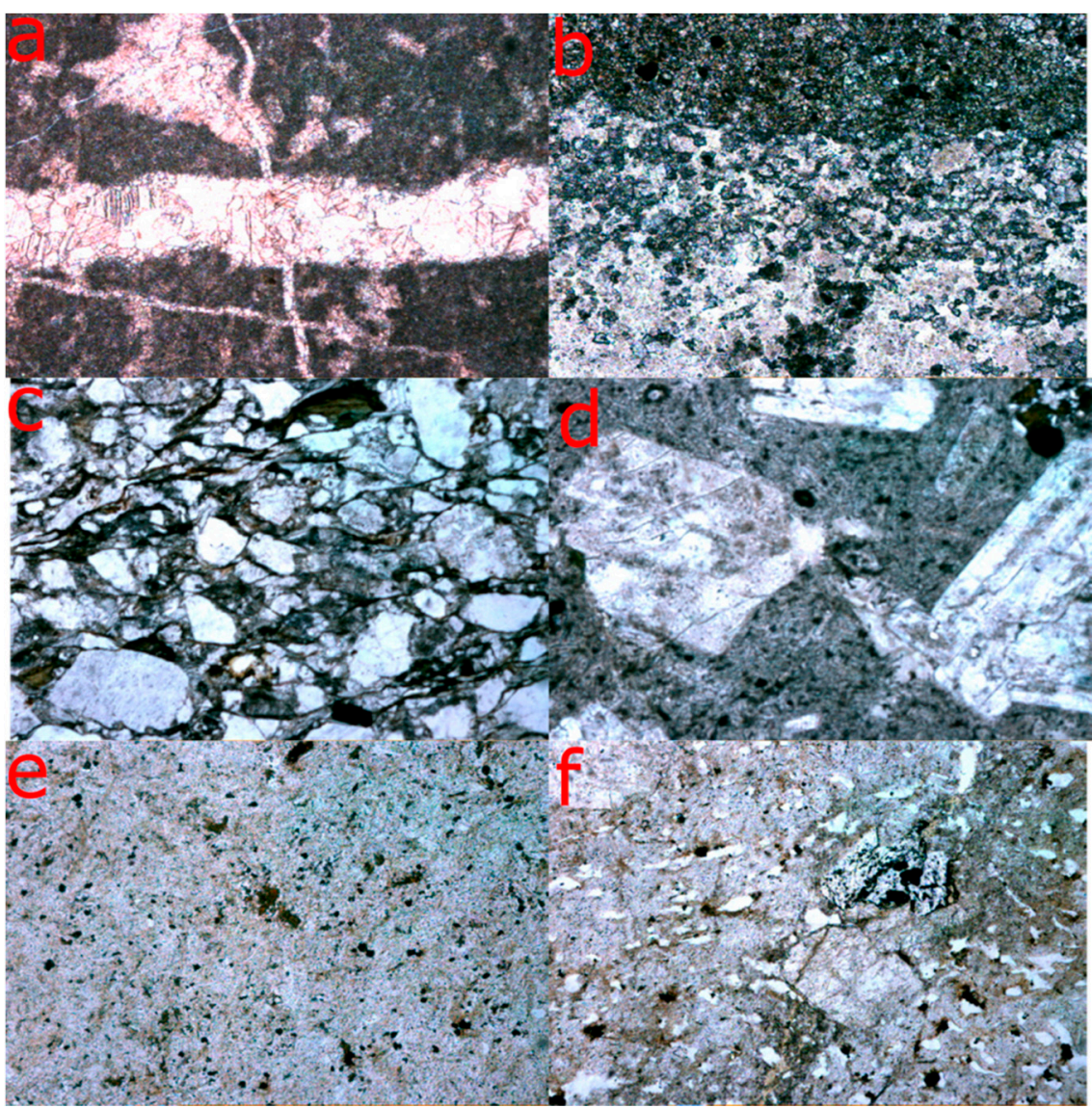

Figure 4. Microphotographs of thin sections for main determined lithotypes in Samobor location: (a) limestone, (b) dolomite; (c) sandstone (greywacke); (d) effusive magmatic; (e) tuff; (f) chert. The width of the microphotographs is $1.7 \mathrm{~mm}$.

Direct measurements of three perpendicular geometrical axes on the pebbles (the longest diameter/length $\mathrm{a}$; the middle diameter/width $\mathrm{b}$; and the shortest diameter/height $\mathrm{c}$ ) were made using a Vernier calliper on all selected pebbles, according to well-established procedure [23,24,27-29]. By comparing the results of these measurements (b/a and $c / b$ ratios), basic grain shape names were attributed: disc, sphere, blade, or rod (Table 2) to all measured pebbles. All results of the measurements are further statistically processed with MS Excel@software. Results are plotted into the Zingg diagrams for pebble shapes [28], which are accentuated with the overlapping curves for the same Wadell sphericity values $(0.3,0.5,0.7$, and 0.9$)$. Measurements and notations are reliable with less than $1 \%$ being outliers. All such extreme values were considered improbable (due to human error) and excluded from plotting in the Zingg diagrams (max. 1-2 measurements per location).

Table 2. Basic types of pebble shapes, after [28].

\begin{tabular}{cccc}
\hline & $\mathbf{b} / \mathbf{a}$ & $\mathbf{c} / \mathbf{b}$ & Shape \\
\hline I. & $>2 / 3$ & $<2 / 3$ & disc \\
II. & $>2 / 3$ & $>2 / 3$ & sphere \\
III. & $<2 / 3$ & $<2 / 3$ & blade \\
IV. & $<2 / 3$ & $>2 / 3$ & rod \\
\hline
\end{tabular}

Although various methods of characterization and classification of pebble shapes have been developed since [30-37], the original method as described by [28] and upgraded by [23,24], attributing original sedimentary environments from flatness ratios, seemed the most appropriate to present the 
results of this study. However, the upgrade [23,24] was originally developed only for carbonate lithologies and specifically for massive micritic limestones, and its application to other lithologies in this study is speculative and only comparative.

Flatness ratios, defined by equation $F=(a+b) / 2 c$, were further calculated for each selected pebble. They usually vary for gravel pebbles between 1.2 and 5 , after $[23,24]$. The original sedimentary environments were discussed and tentatively attributed according to Table 3. Significant limitations for the application and interpretation of flatness ratios in this study are considered and further discussed.

Table 3. Flatness in various sedimentary environments, after $[23,24]$.

\begin{tabular}{lc}
\hline \multicolumn{1}{c}{ Pebble Deposits } & Flatness \\
\hline Potholes in river channel & $1.2-1.6$ \\
Ground moraine & $1.6-1.8$ \\
Fluvioglacial & $1.7-2.0$ \\
Beach (sea) & $2.3-3.8$ \\
Beach (lake) & $2.3-4.4$ \\
Frost-rived & $2.0-3.1$ \\
Rivers in moderately warm climate & $2.5-3.5$ \\
\hline
\end{tabular}

\section{Results}

The results of lithological determinations and major ( $>4 \%$ ) defined lithotypes (limestones, dolomites, sandstones) as well as minor $(<4 \%)$ lithotypes (effusive magmatics, cherts and tuffs) are statistically presented for all samples. Pebbles of breccias, conglomerates, marls, shales, and quartz are determined as accessories $(<1 \%)$. Distributions of major lithotypes at locations along Sava River watercourse, from the west downstream to the east (from Samobor to Ivanja Reka), are presented in Figure 5, and distributions of minor lithotypes in Figure 6.

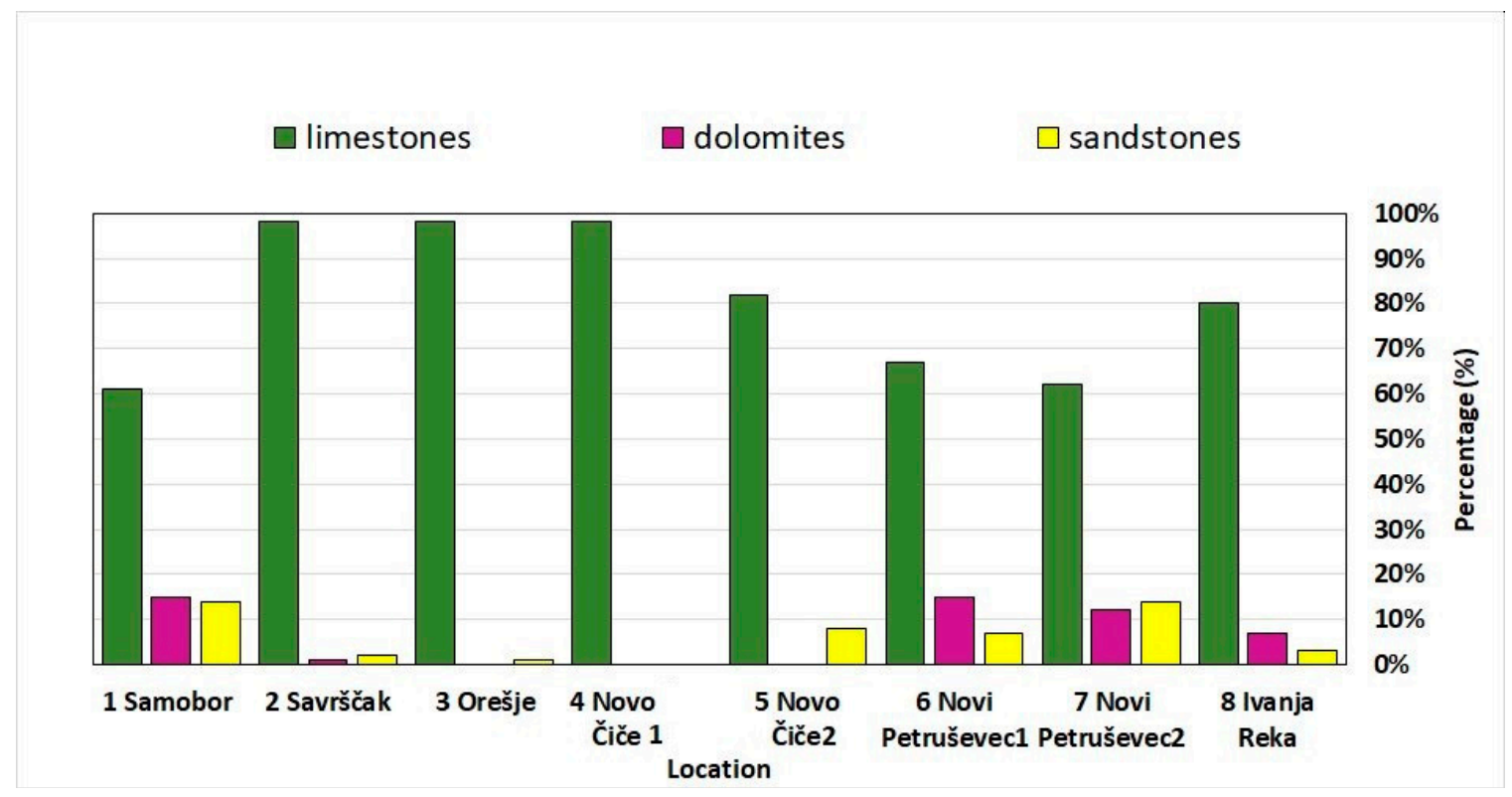

Figure 5. Distributions of major lithotypes of the pebbles at locations. 


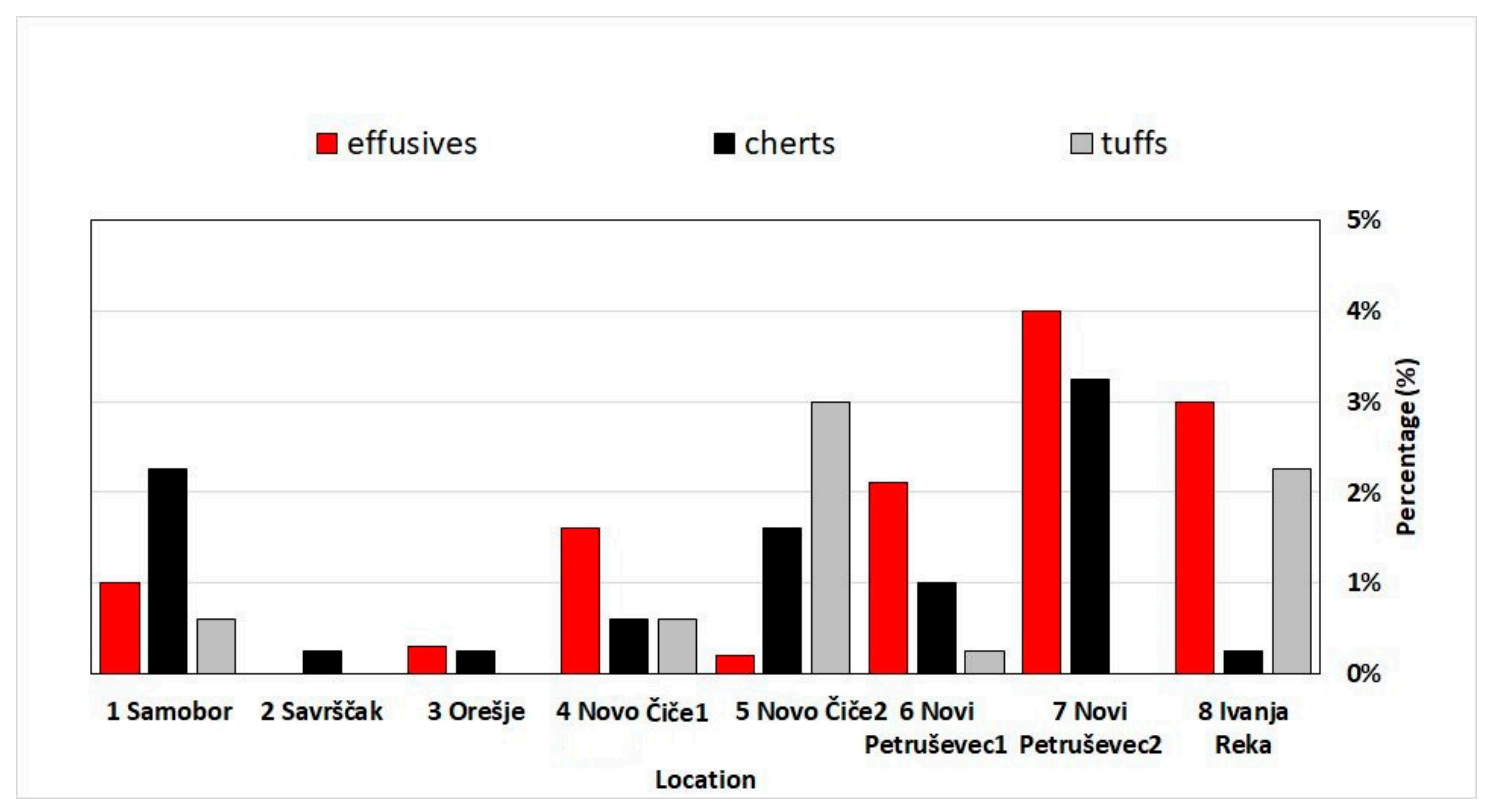

Figure 6. Distributions of minor lithotypes of the pebbles at locations.

The most common lithotype in all samples and at all locations are limestones, ranging from $63 \%$ (Samobor) to 97\% (Savršćak, Orešje and Novo Čiče) in the west, and progressively decreasing towards east (down to $62 \%$, in Novi Petruševec 1). The major contribution for limestone pebbles is from the Alpine region upstream the Sava River, and they are accumulated in the plain before the narrowing between Medvednica and Samoborska Gora (Figure 1). Dolomites are the second most common lithotype determined, which is significantly abundant in Samobor location (15\%). Possible local input in this part is attributed to Triassic dolomites, documented in the nearby Samoborska Gora and Marijagorička brda Hills and in the SW parts of Medvednica [9,38-41]. It was determined that proportions of dolomites strongly decrease downstream $(<1 \%)$, but significantly increase $(7-16 \%)$ in Novi Petruševec 1,2 and Ivanja Reka locations. Sandstones are the next common lithotype, with up to $15 \%$ in Samobor (west) and Novi Petruševec (east) locations, as well as up to $7 \%$ in other locations. Effusive magmatics, cherts, and tuffs are irregularly distributed, with up to $3-4 \%$ being determined. Pebbles from breccias, conglomerates, quartz, shales, and marls were also determined in minor amounts $(<1 \%)$, showing no significant distribution patterns. However, the effect of statistical "dilution" of the minor lithotypes by predominance of one major lithotype is also considered and further discussed.

By comparing their measured axes (according to Table 2), pebble shapes (disc, sphere, blade, or rod) were quantitatively defined in each sample. Pebble shapes were determined for all main lithotypes and the results are presented in the Zingg diagrams (accentuated with the curves for the same Wadell sphericity values) and in histograms (Figures 7-14) for all locations, from the west downstream to the east. In Samobor, the predominant limestone and dolomite pebbles have mainly disc to mildly spherical shapes (Figure 7). Subordinate lithotypes (sandstones, effusives, cherts, and tuffs) show more scattered distributions of pebble shapes, with sandstones being the most diverse.

In Savršćak, the predominance of limestone pebbles is significant, and they are mainly disc- to sphere-shaped (Figure 8). Subordinate dolomite and sandstone pebbles show similar distributions.

In Orešje, the predominant limestone pebbles are also mainly disc-shaped (Figure 9). Other lithotypes present are insignificant, as well distributions of pebble shapes. Sandstone pebbles have mainly disc shapes, followed by blade and rod shapes. 


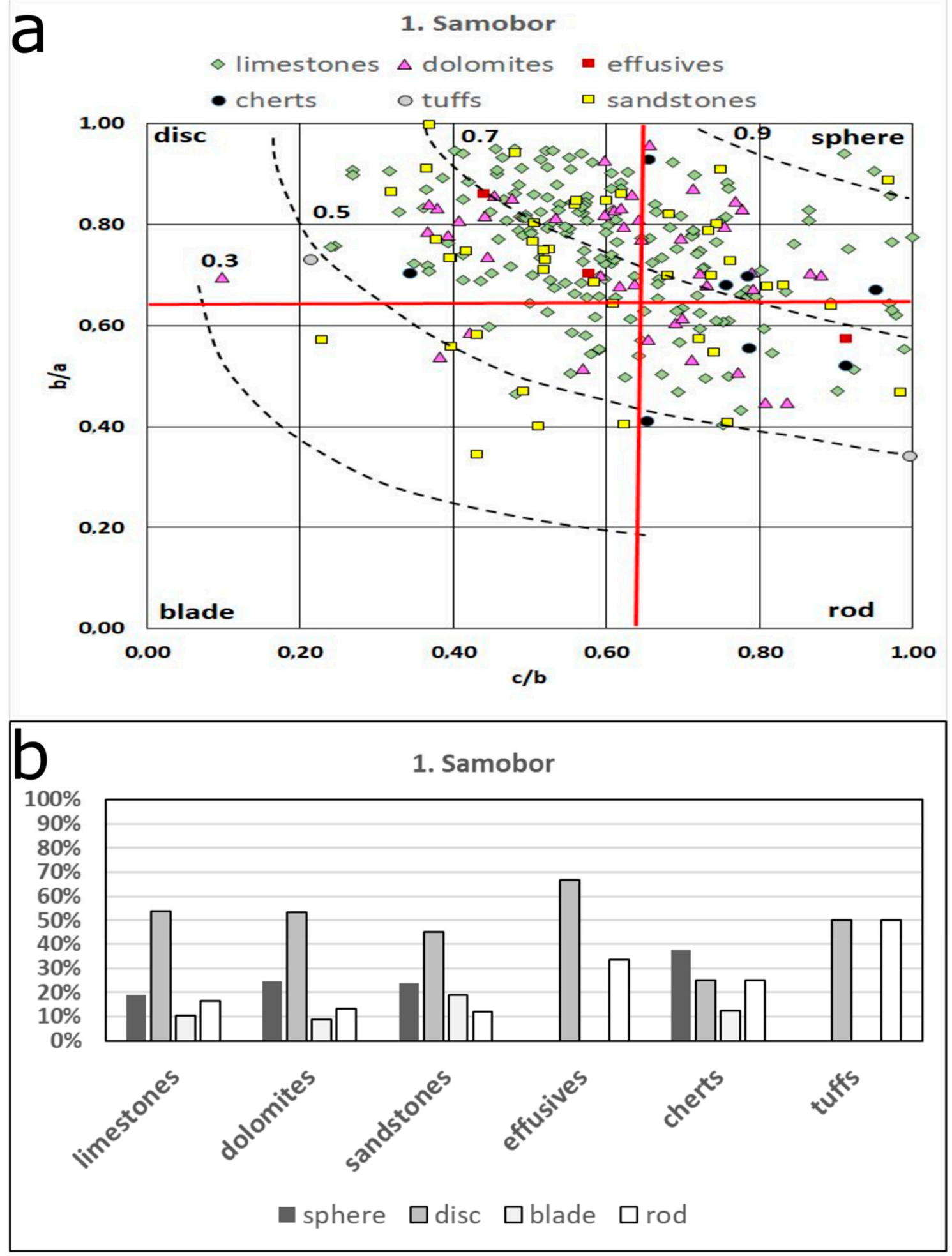

Figure 7. Pebble shapes of main lithotypes in Samobor: (a) Zingg diagram; (b) histograms. 


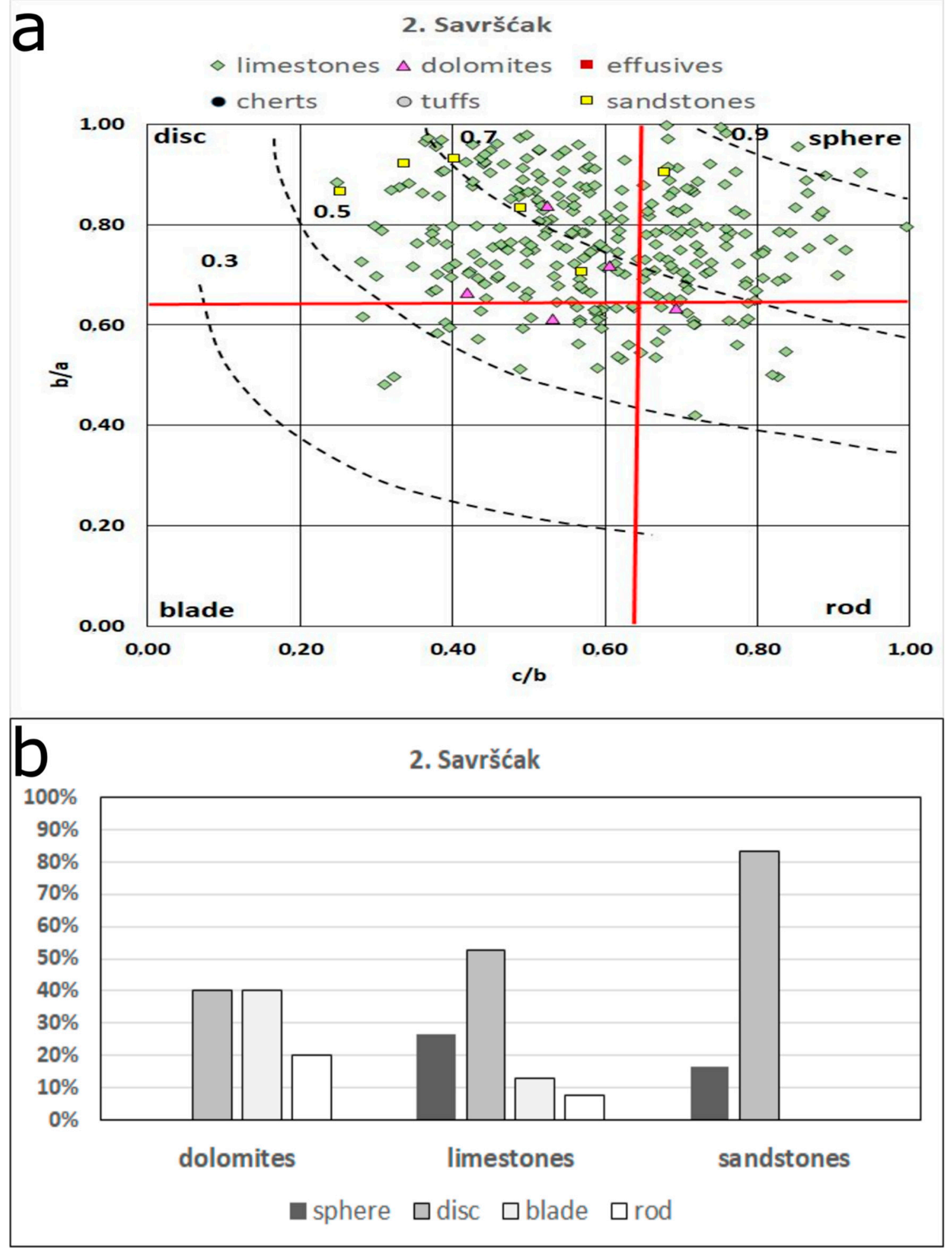

Figure 8. Pebble shapes of main lithotypes in Savršćak: (a) Zingg diagram; (b) histograms. 


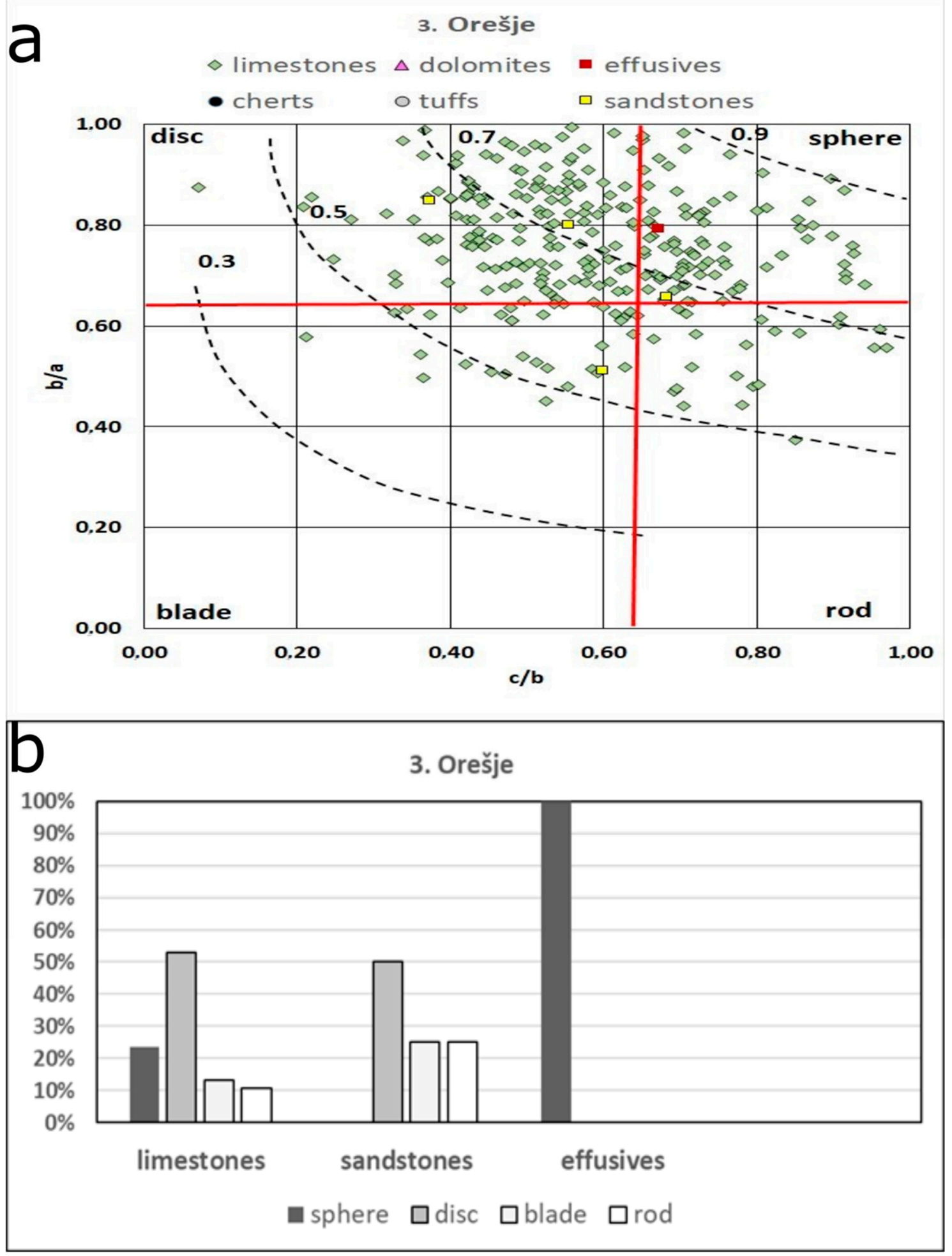

Figure 9. Pebble shapes of main lithotypes in Orešje: (a) Zingg diagram; (b) histograms. 


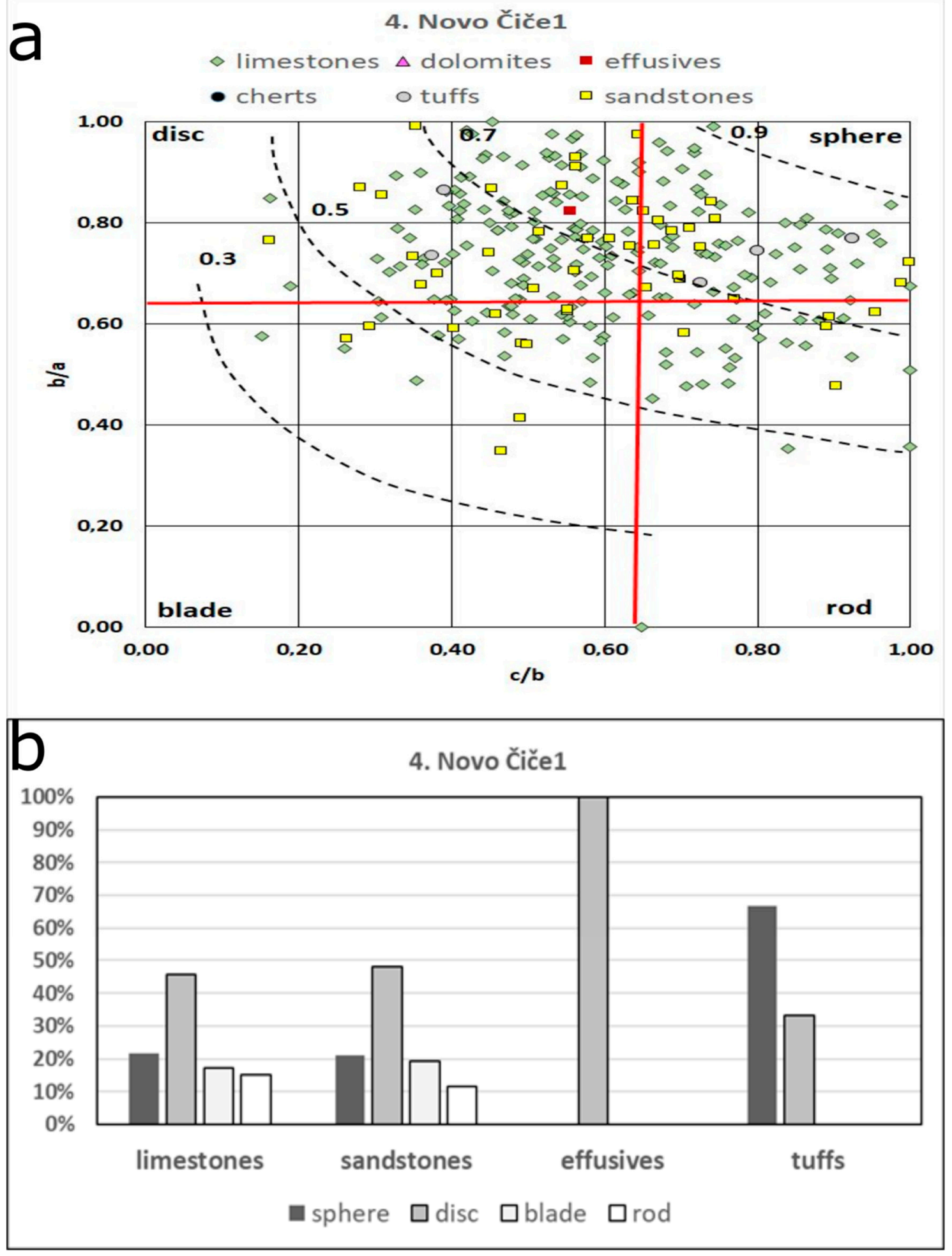

Figure 10. Pebble shapes of main lithotypes in Novo Čiče 1: (a) Zingg diagram; (b) histograms. 


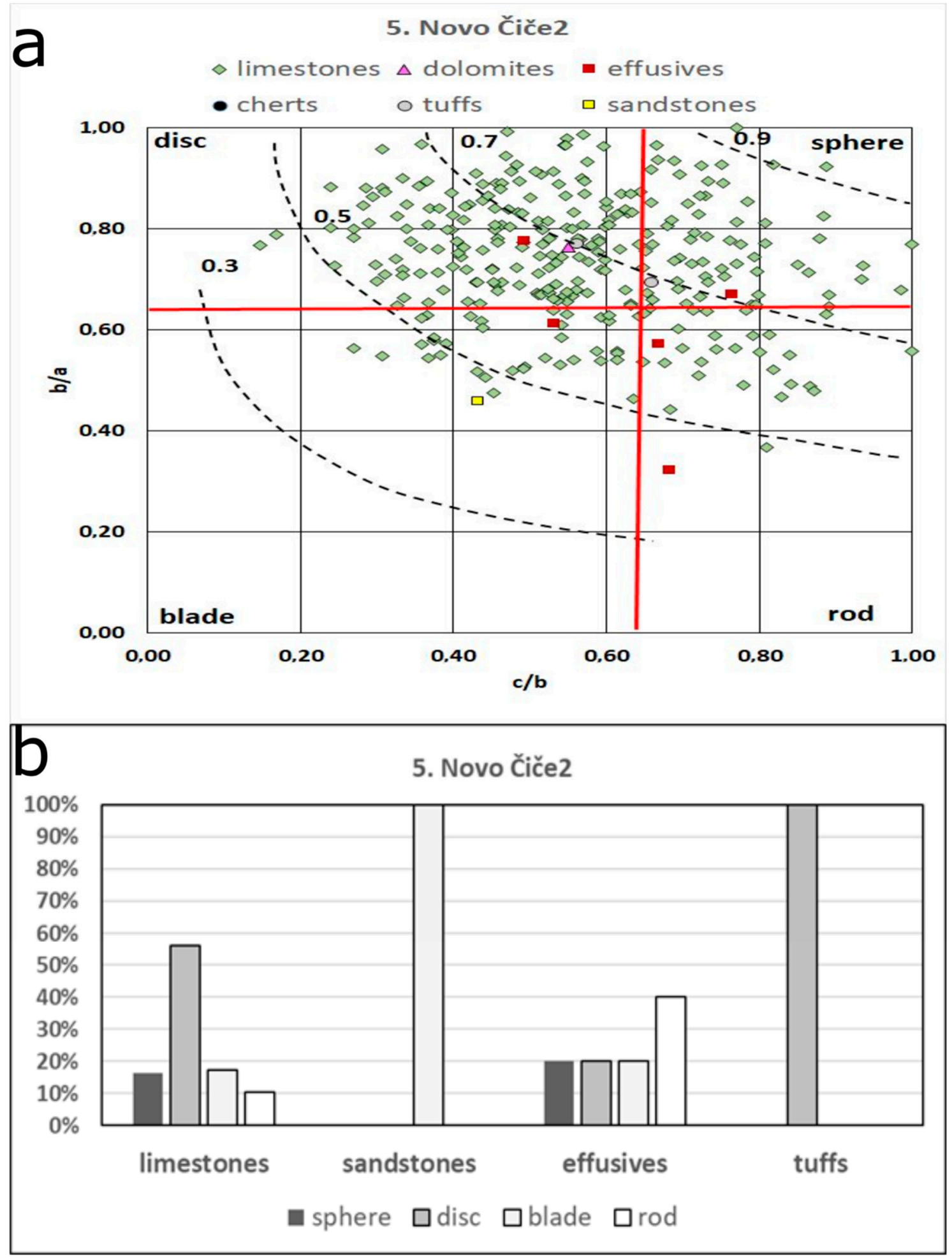

Figure 11. Pebble shapes of main lithotypes in Novo Čiče 2: (a) Zingg diagram; (b) histograms. 

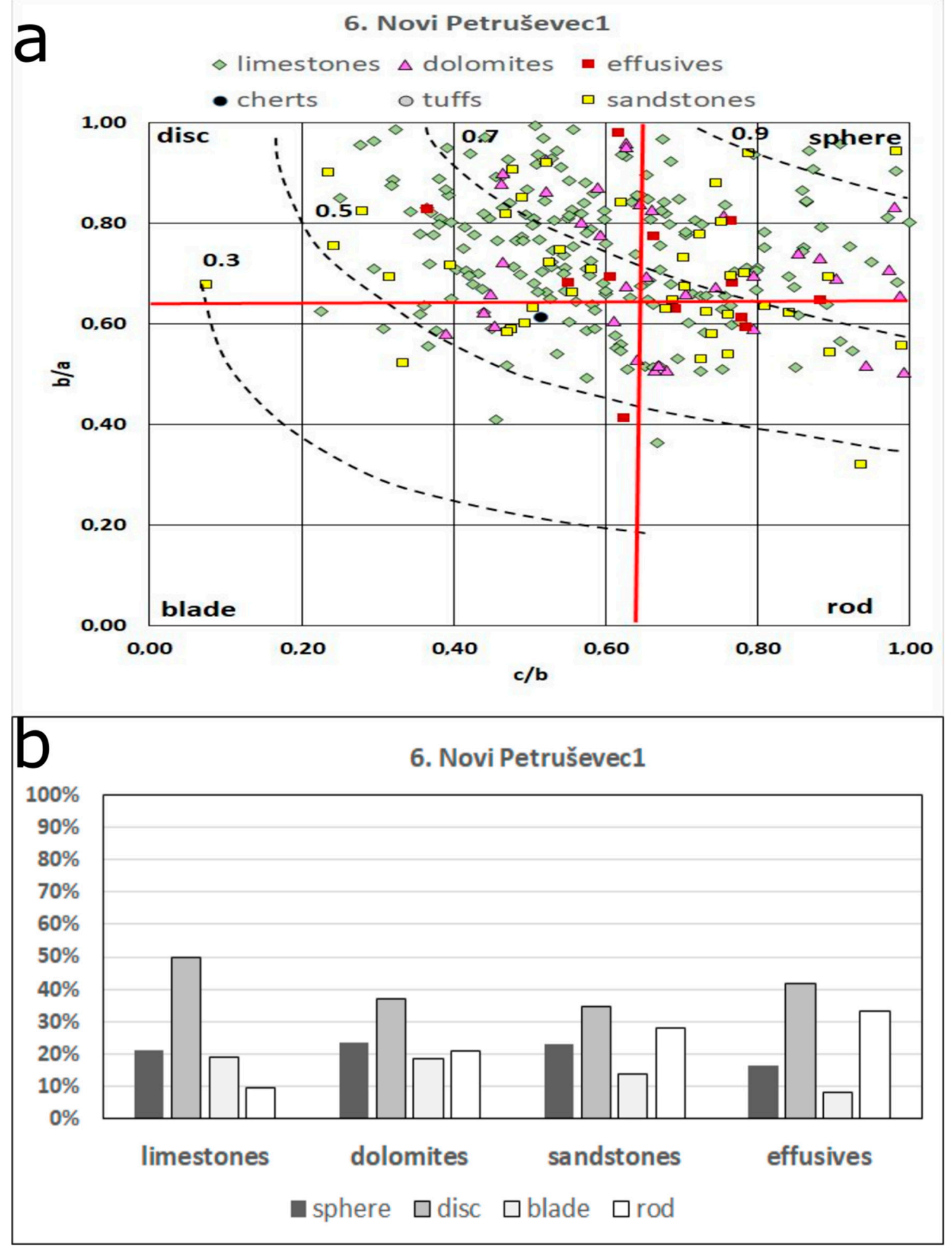

Figure 12. Pebble shapes of main lithotypes in Novi Petruševec 1: (a) Zingg diagram; (b) histograms. 

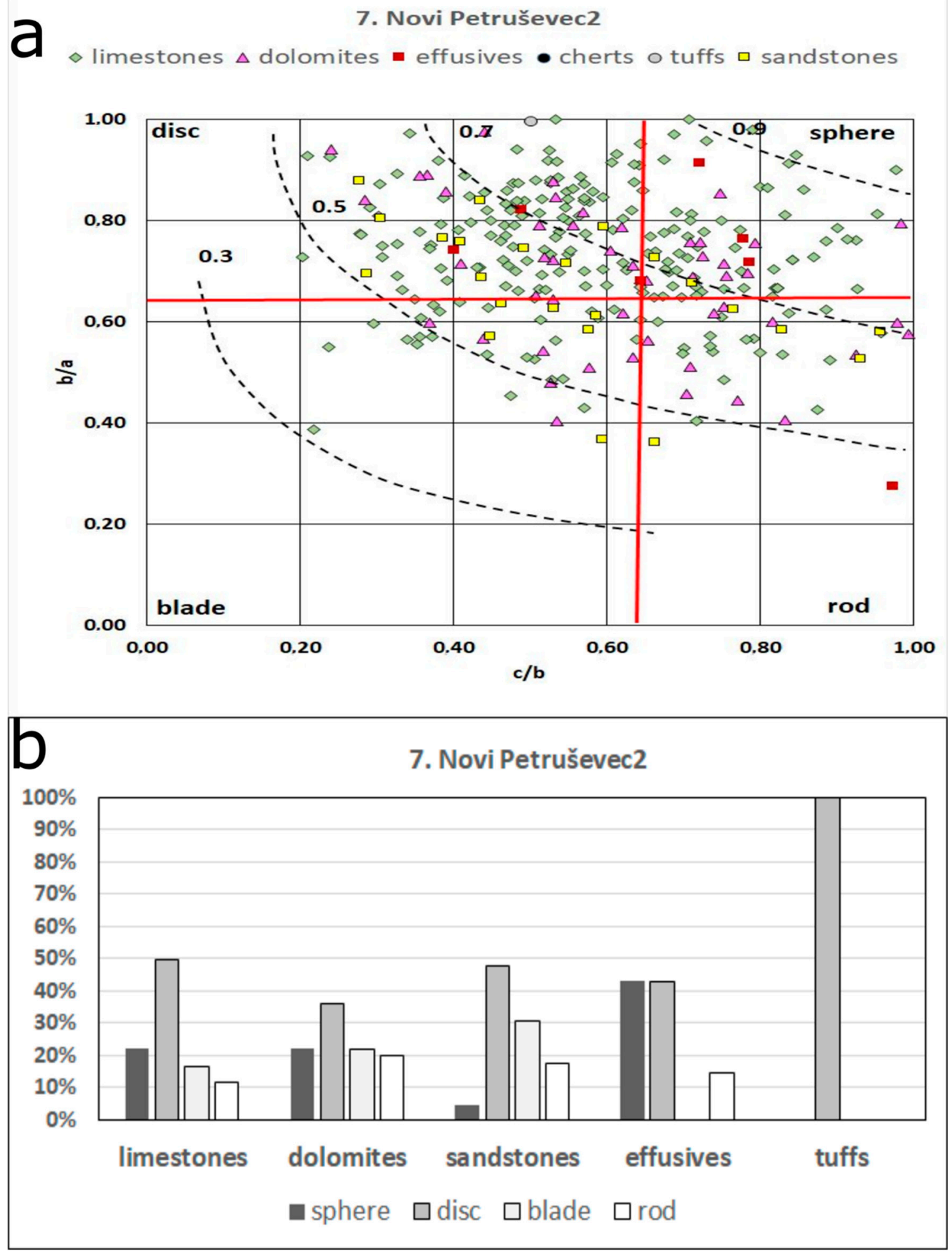

Figure 13. Pebble shapes of main lithotypes in Novi Petruševec 2: (a) Zingg diagram; (b) histograms. 


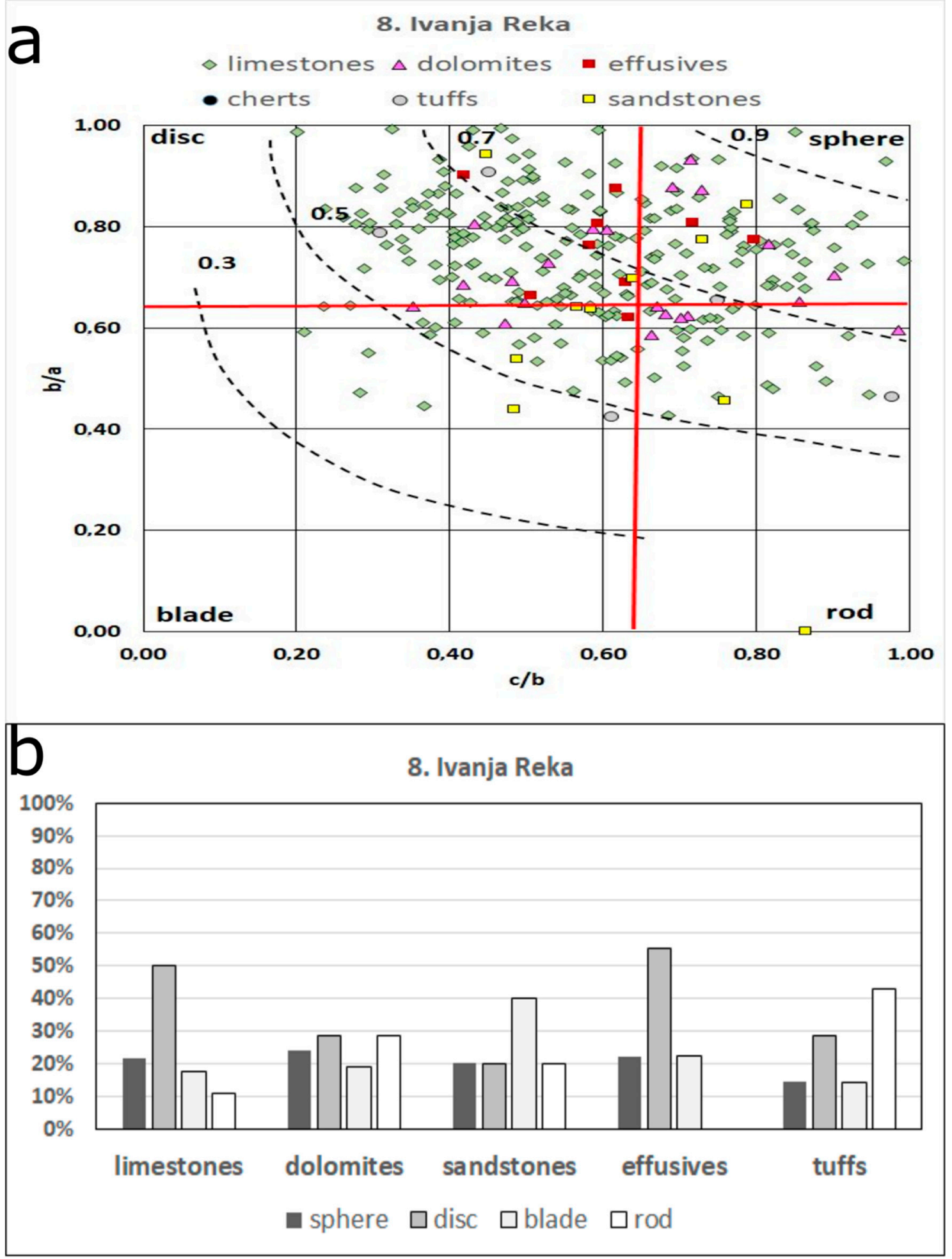

Figure 14. Pebble shapes of main lithotypes in Ivanja Reka: (a) Zingg diagram; (b) histograms.

In Novo Čiče 1, the scattered pattern of sandstone pebble shapes appears again (Figure 10), as previously observed in Samobor (Figure 7). Predominant limestone pebbles retained mainly disc and sphere shapes.

In Novo Čiče 2, effusive magmatic pebbles increase, having more elongated (blade to rod) shapes (Figure 11). Predominant limestones retained mainly disc shapes. 
Downstream towards the east, in Novi Petruševec 1, limestone pebbles slightly decrease, retaining mainly disc shapes (Figure 12). All other lithotypes increase, showing scattered distributions in pebble shape.

In Novi Petruševec 2 (Figure 13), there are similar proportions of lithotypes present and distributions of pebble shapes as observed for Novi Petruševec 1 (Figure 12). Limestones, dolomites, and sandstone pebbles mainly have disc shapes, and effusive magmatic pebbles have disc and sphere shapes.

In Ivanja Reka, the far east location, all major lithotypes are significantly present again. Limestones are predominant and slightly increase again, having mainly disc to sphere pebble shapes (Figure 14). Sandstone pebbles with mainly blade shapes prevail.

Generally, regardless of lithotypes, disc pebbles prevail (45-50\%) in all locations along the observed traverse (Figure 15). Sphere pebbles are less abundant (16-26\%), while blade (11-16\%) and rod (8-15\%) pebbles are subordinately present. Disc, sphere, and rod pebbles are more or less equally distributed along observed the Sava River watercourse, while blade pebbles discretely increase downstream toward east.

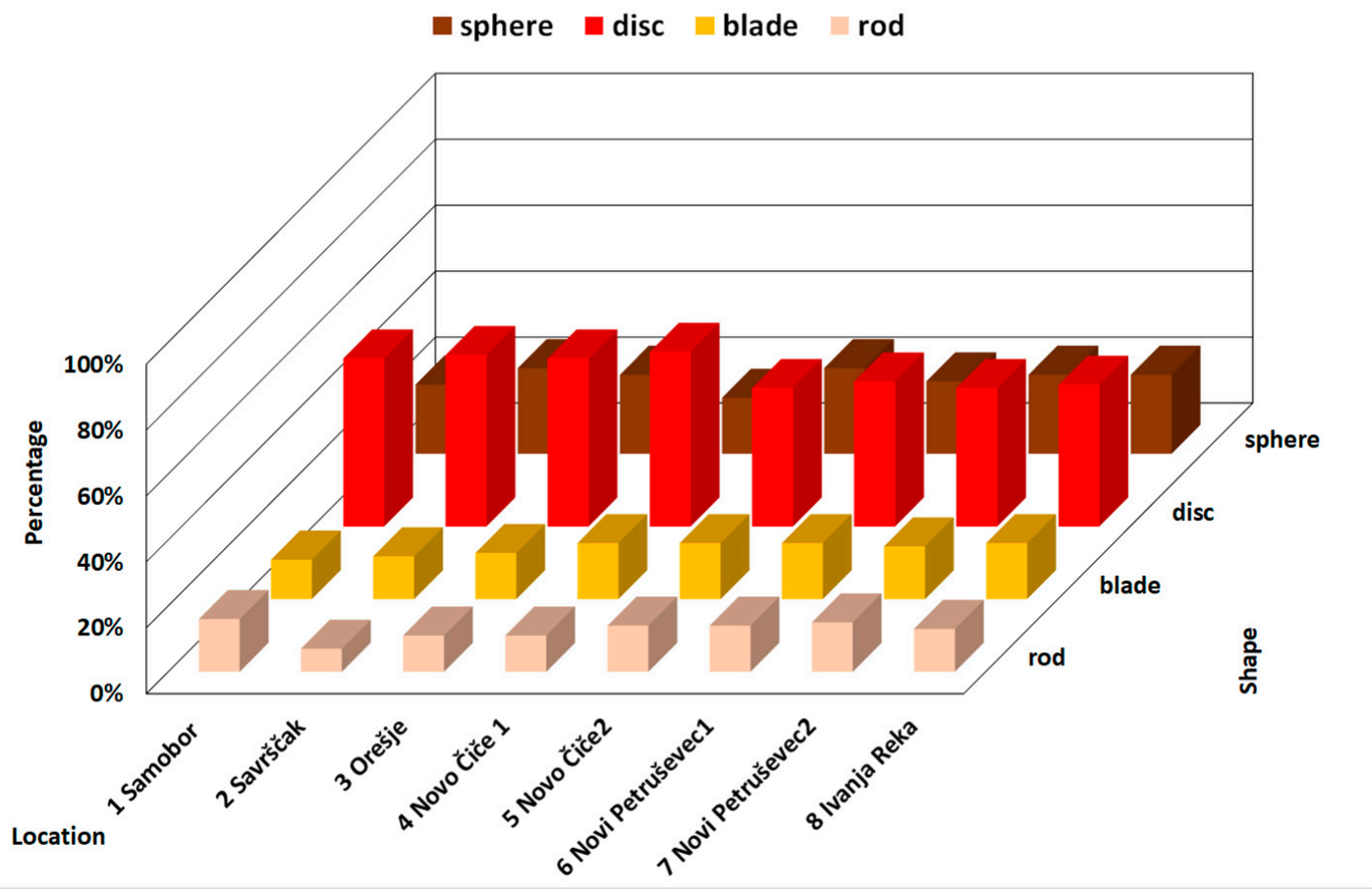

Figure 15. Distribution of pebble shapes at locations.

Comparisons of lithotype distributions (Figures 5 and 6) and pebble shape distributions according to the lithotypes (Figures 7-14) and regardless of lithotypes (Figure 15) were made and are further discussed. Potential original sedimentary environments of the pebbles (moraine, riverbed, and lake beach), determined by measuring their diameters and calculating flatness ratios (according to [23,24], see Table 3), were aimed to be tentatively attributed (Figure 16). Since these ratios depend also on different lithologies and hydrodynamic conditions during the transport of the pebbles, these attributions are further critically evaluated. 


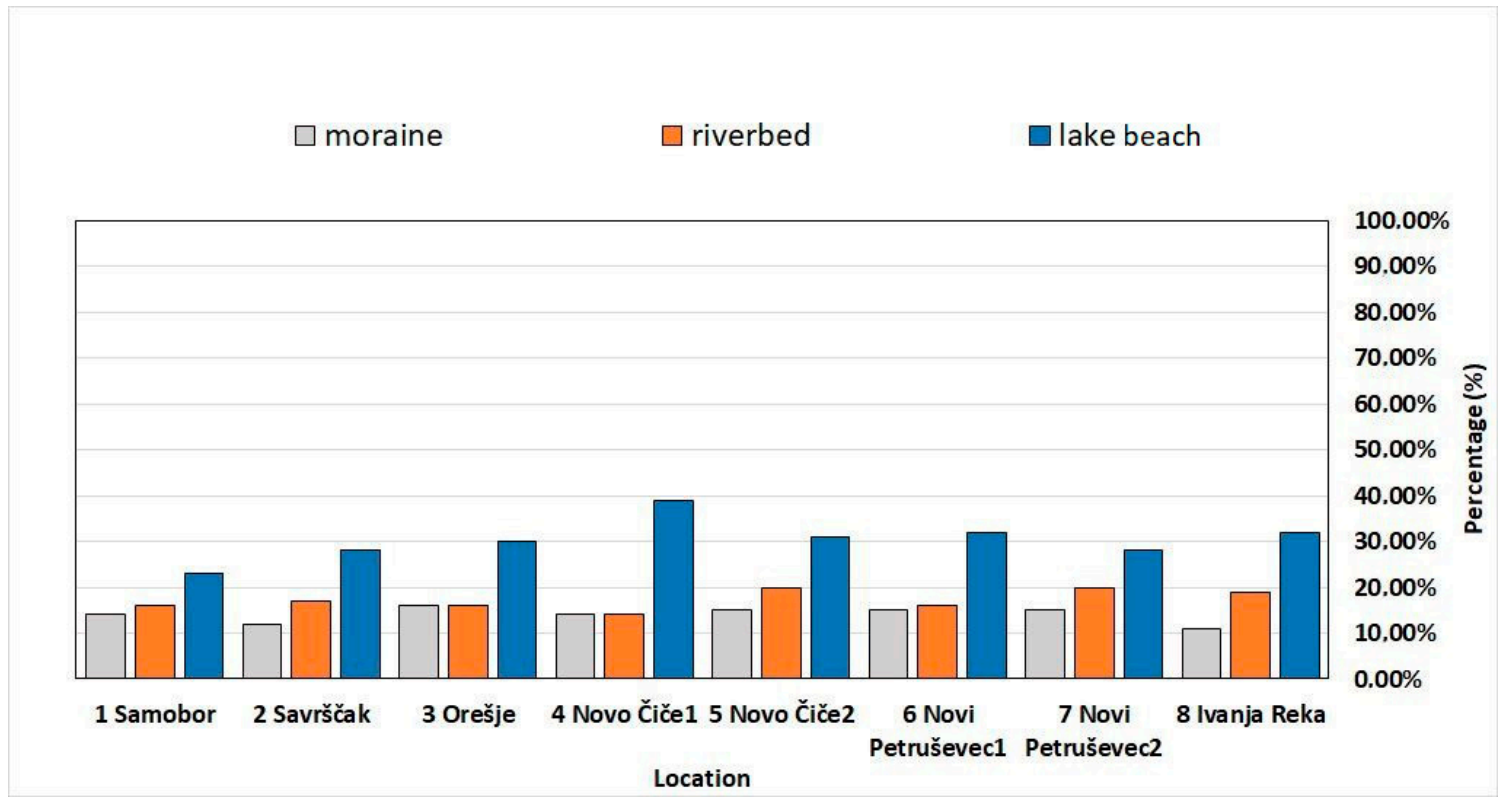

Figure 16. Tentatively attributed original sedimentary environments at locations.

\section{Discussion}

Comparisons of lithotype distributions (Figures 5 and 6) show predominance of carbonate lithologies (limestones and dolomites) of mainly Alpine provenance (from Triassic and Jurassic carbonate formations in Slovenia), with a possibly significant input of dolomites from the local sources in the west (Triassic deposits of Medvednica and Samoborska Gora-left side in Figure 1, see also [9,38]). Nearby location 3 (Orešje), significant change in the Sava River watercourse is visible: through the narrowing between Medvednica and Samoborska Gora at Podsused, it enters the Zagreb alluvial plain and flows further eastwards as a meandering river with reduced flow. This change in watercourse is mainly reflected in the distribution of Holocene gravel pebbles and partly by the morphometric characteristics, which mostly depend on lithology. Accumulation of predominantly carbonate pebbles occurred at locations 1-3. This is followed by incision and deep erosion of the riverbed (down to the underlying Pleistocene deposits) at the knickpoint near Podsused. These two processes influenced the distribution of lithotypes at downstream locations. Sandstones are also abundant in the west and in the far east locations, while almost lacking in the middle part of the observed traverse. This implies probable local inputs from the SW limbs of Medvednica and Samoborska Gora in the west, and from SE parts of Medvednica in the east. Minor lithotypes (effusive magmatics, cherts, and tuffs) increase significantly towards east, suggesting also possible lateral input from the eastern parts of the Medvednica (see [8,38,41-43]). On the other hand, illusory "dilution" of minor lithologies, as is the case here with predominant limestones transported from a strongly enhanced source (by the Sava River, from the Alps), can be also easily misinterpreted. It can give a false impression of some local source for minor lithotypes at locations where main transport of predominant limestone pebbles is partly prevented (i.e., in locations 4, 5, 6, and 7, after narrowing at location 3-see Figure 1.)

Pebble shapes in alluvial sediments are primarily influenced by lithology and fabric, and then by hydrodynamic conditions during transport. Shale and schist pebbles are usually prone to form platy pebbles, and not likely to form rod or sphere shapes, and the same can be stated for thin layered/laminated limestones, cherts, siltites, and sandstones. More homogeneous rocks (thick layered and massive limestones and dolomites, quartzites, or marbles) form sphere, disc, or generally isometric pebble shapes. The approach toward an ideal sphere pebble shape also correlates well with the increasing hydrodynamic conditions or with relatively long transport [26]. Significant amount of limestone pebbles which is the predominant lithotype in all investigated locations, are of intermediate 
to moderately high sphericity and have mainly disc to sphere shapes (Figures 7-14), thus implying relatively long riverbed transport.

When the pebble shapes and corresponding lithotypes are compared (Figures 7-14), disc and sphere pebble shape distributions correlate well with two major lithologies-limestones and dolomites (Figure 5). The contribution of limestone and dolomite pebbles with predominantly disc and sphere shapes is, therefore, significant to characterise the overall pebble distribution (Figure 15), and it implies similar sources (predominantly more distant, and possibly some local) and similar transport conditions. On the other hand, the third major lithotype, sandstones, show more scattered pebble shape distributions in all locations where they are significantly present: in the west as well as in the far east locations. Almost equally present sphere, disc, blade, and rod shapes reflect the possible heterogeneity of their fabrics, tentatively indicating multiple sources. Considering that fact, together with the significant abundance in the west and east (Figure 5), local sources and possible lateral input by streams from Medvednica and Samoborska Gora are possible. Pebble shape distributions of minor lithotypes (effusive magmatics, cherts, and tuffs) are also scattered, and together with their abundances (Figure 6) suggest, at least some, local sources. However, the previously mentioned effect of "dilution" on these minor lithologies should be also considered, and more detailed petrographic comparisons with nearby areas should be performed in order to precisely determine provenance of the minor lithotypes.

The flatness ratios of pebbles of the same lithotypes vary according to the conditions in which they are originated as a pebble (weathered into a clast) and the hydrodynamic conditions during transport. The relationship of flatness ratios to "original sedimentary environments" is specifically determined and attributed only for limestones [23,24], which also happens to be the major lithotype determined in this study. However, applicability of this concept in this study is only tentative, and distribution of "originally moraine, riverbed, and lake beach pebbles" (Figure 16) indicate "lake beach environments" as prevailing in all locations. Sandy gravel lake deposits are often recorded in the underlying Middle Pleistocene deposits [21,22], and the predominance of pebbles from such environments indicate redeposition further downstream during the Holocene. However, the potential for reworking of gravel fraction from these older deposits is limited to those parts of the watercourse in which water energy suddenly increase, such as mentioned, narrowing at location 3 (see Figure 1). Pebbles tentatively interpreted as originated in "moraine environments" are almost equally distributed in all locations and possibly indicate glacial weathering and transport, prior to Holocene alluvial transport along Sava River watercourse and riverbed deposition. Original locations for predominantly carbonate "moraine pebbles" (pebbles with retained flatness ratios indicating glacial environments) are assumed to be within the Triassic and Jurassic carbonate formations in Slovenia. Glaciation boundaries are determined and drawn within these formations in the spring area of the Sava River, as well as further downstream [44]. Climatic changes with glacial and interglacial periods, followed by sudden warming and increased tectonic dynamics in the Holocene [22] favour intensive riverbed transport and sedimentation of relatively well sorted gravels. For that reason, Holocene gravels contain predominantly carbonate pebbles of mainly Alpine provenance, which are overlying Pleistocene deposits.

Pebbles with flatness ratios indicating riverbed can be easily expected in Holocene gravels of the Sava River. However, their similar proportions (15-20\%) as "moraine pebbles" (11-18\%) and the predominance of "lake beach pebbles" (20-40\%) in both possibly indicate that riverbed transport has only a minor influence on the flatness ratios of these gravel pebbles. Tentatively interpreted, older moraine pebbles of Alpine provenance (most of the limestones and some of the dolomites) as well as lake beach pebbles possibly redeposited from the underlying Pleistocene lake deposits possibly retained their flatness in Holocene lower energy meandering river environments along the observed Sava River watercourse.

Holocene-aged Sava River gravels thus represent a kind of environmental products, similar to products of the "Los Angeles Abrasion Resistance Test" [45,46], which is applied on various types of rocks in simulated conditions at the laboratory. The morphometric characteristics and pebble shapes of 
predominant carbonate lithotype can thus be compared, in future studies, with the physicomechanical properties of carbonates from nearby the Samoborska Gora and Medvednica, as described by [40,41,47].

\section{Conclusions}

Limestones, dolomites, and sandstones are the major lithotypes observed in Holocene pebbles from the Sava River gravels, while effusive magmatics, cherts, and tuffs are present as minor lithotypes. Their distributions vary along the observed traverse, downstream from Samobor to Ivanja Reka, indicating distant Alpine provenance as well as possible local input in the west for the two main lithologies of limestones and dolomites. Sandstone pebble distribution indicates possible local sources at both ends of the traverse, in the west, as well as in the east. Minor lithotype distributions indicate possible local input in the east.

The predominant disc and sphere shapes of limestone and dolomite pebbles imply similar sources and transport conditions (mainly distant, and some local). Scattered distributions of sandstones pebble shapes indicate possible multiple sources, some of them highly probable as local, from the SW Medvednica and Samoborska Gora in the west as well as from the SE Medvednica in the east. Scattered distributions of pebble shapes for minor lithotypes show no significantly recognized provenance.

The tentatively interpreted "original sedimentary environments" for the main pebble lithotypes, as calculated from their flatness ratios, possibly indicates predominant lake beach pebbles, followed by moraine and riverbed pebbles, but these results should be further investigated.

Author Contributions: Conceptualization, J.V. and U.B.; Formal analysis, N.M.B., J.V. and U.B.; Investigation, J.V., N.M.B. and U.B.; Methodology, J.V. and U.B.; Software, N.T. and N.M.B.; Supervision, J.V. and U.B.; Validation, T.M.; Visualization, N.M.B., N.T. and T.M.; Writing—original draft, U.B.; Writing—review \& editing, J.V., N.T., T.M. and U.B. the term explanation. All authors have read and agreed to the published version of the manuscript.

Acknowledgments: The authors are grateful for partial support from the project "Mathematical methods in geology IV" (led by T.M.). Funds were given from the University of Zagreb, for the year 2019.

Conflicts of Interest: The authors declare no conflicts of interest.

\section{References}

1. Nakić, Z.; Ružičić, S.; Posavec, K.; Mileusnić, M.; Parlov, J.; Bačani, A.; Durn, G. Conceptual model for groundwater status and risk assessment - case study of the Zagreb aquifer system. Geol. Croat. 2013, 66, 55-76. [CrossRef]

2. Vujević, M.; Posavec, K. Identification of groundwater level decline in zagreb and Samobor-Zaprešić aquifers since the sixties of the twentieth century. Rud. Geolo scaron; ko-Naft. Zb. 2018, 33, 55-64. [CrossRef]

3. Kapuralić, J.; Posavec, K.; Kurevija, T.; Macenić, M. Identification of river Sava temperature influence on groundwater temperature of the Zagreb and Samobor-Zaprešić aquifer as a part of shallow geothermal potential. Rud. geoloEscaron;ko-Naft. Zb. 2018, 33, 59-69. [CrossRef]

4. Brkić, Željka The relationship of the geological framework to the Quaternary aquifer system in the Sava River valley (Croatia). Geol. Croat. 2017, 70, 201-213. [CrossRef]

5. Grizelj, A.; Bakrač, K.; Horvat, M.; Avanić, R.; Hećimović, I. Occurrence of vivianite in alluvial Quaternary sediments in the area of Sesvete (Zagreb, Croatia). Geol. Croat. 2017, 70, 41-52. [CrossRef]

6. Trenc, N.; Matoš, B.; Velić, J.; Perković, D. Application of GIS Procedure for River Terrace extraction from LiDAR- based DEM: Sava River Valley NW of Zagreb, Croatia. Rud. Geološko Naft. Zb. 2018, 34, 59-70.

7. Ružičić, S.; Kovač, Z.; Tumara, D. Physical and chemical properties in relation with soil permeability in the area of Velika Gorica well field. Rud. Geološko Naft. Zb. 2020, 33, 73-82. [CrossRef]

8. Šikić, K.; Basch, O.; Šimunić, A. Basic Geological Map of SFR Yugoslavia, 1:100000, Geology of the Zagreb sheet; Federal Geol. Institute: Belgrade, Serbia, 1979; p. 81. (In Croatian).

9. Basch, O. Basic Geological Map of SFR Yugoslavia, 1:100000, Geology of the Ivanić-Grad sheet; Federal Geol. Institute: Belgrade, Serbia, 1983; p. 66. (In Croatian).

10. Šikić, K.; Basch, O.; Šimunić, A. Basic Geological Map of SFR Yugoslavia, 1:100000, Zagreb sheet, L33-80; Federal Geol. Institute: Belgrade, Serbia, 1977; (In Croatian). 
11. Basch, O. Basic Geological Map of SFR Yugoslavia, 1:100000, Ivanić-Grad sheet, L33-81; Federal Geol. Institute: Belgrade, Serbia, 1983; (In Croatian).

12. Borčić, D.; Capar, A.; Čakarun, I.; Kostović, K.; Miletić, P. New data on dependence of underground water levels and Sava River water levels in the area around the city of Zagreb. Geol. Vjesn. 1968, 21, 311-316. (In Croatian).

13. Crnković, B.; Bušić, M. Mineralogical and petrological composition of the Sava River sediment. In Proceedings of the 30th anniversary of the RGN Faculty (1939-1969), Zagreb, Croatian, 1970; pp. 133-140. (In Croatian).

14. Kovačević, S.; Capar, A. Underground water researches in Sava River alluvium near Samobor. In Proceedings of the 2nd Jugosl. Simp. Hidrogeol. Eng. Geol, Belgrade, Serbia, 1972. (In Croatian).

15. Šimunić, A.; Basch, O. The stratigraphy of Quaternary sediments in the Zagrebačko Posavlje. Geol. Vjesn. 1975, 28, 153-164. (In Croatian).

16. Babić, Ž.; Čakarun, I.; Sokač, A.; Mraz, V. About the geology of Quaternary deposits of the Drava River basin. Geol. Vjesn. 1978, 30, 43-61. (In Croatian).

17. Šimunić, A.l.; Novosel-Škorić, S.; Piljurović, L.J. Lithological correlation and chronostratigraphic delimitation of Quaternary sediments at the location Prevlaka southeast of Zagreb. Geol. Vjesn. 1988, 41, 167-179. (In Croatian).

18. Geological Map of the Republic of Croatia at a scale 1:300.000; Croatian Geological Survey: Zagreb, Croatian, 2009; Available online: http://webgis.hgi-cgs.hr/gk300/default.aspx (accessed on 26 February 2020).

19. Guide to the Geological Map of the Republic of Croatia at a scale 1:300.000; Velić, I.; Vlahović, I. (Eds.) Croatian Geological Survey: Zagreb, Croatian, 2009; p. 141. (In Croatian)

20. Velić, J.; Saftić, B. Subsurface Spreading and Facies Characteristics of Middle Pleistocene Deposits between Zaprešić and Samobor. Geol. Vjesn. 1991, 44, 69-82.

21. Velić, J.; Durn, G. Alternating Lacustrine-Marsh Sedimentation and Subaerial Exposure Phases During Quaternary: Prečko, Zagreb, Croatia. Geol. Croat. 1993, 46, 71-90.

22. Velić, J.; Saftić, B.; Malvić, T. Lithological Composition and Stratigraphy of Quaternary Sediments in the Area of the "Jakuševec", Waste Depository (Zagreb, Northern Croatia). Geol. Croat. 1999, 52, 119-130.

23. Müller, G. Methods in Sedimentary Petrology; Schweizerbart: Stuttgart, Germany, 1967; p. 283.

24. Cailleux, A. Morphoskopische Analyse der Geschiebe und Sandkörner und Ihre Bedeutung für die Paläoklimatologie. Acta Diabetol. 1952, 40, 11-19. [CrossRef]

25. Tišljar, J. Sedimentary Rocks; Školska knjiga: Zagreb, Croatian, 1994; p. 421. (In Croatian)

26. Southard, J. Sedimentary Geology; MIT Open Course Ware: Cambridge, MA, USA, 2007; p. 312.

27. Wentworth, C.K. The shapes of beach pebbles. Prof. Pap. 1923, 75-83.

28. Zingg, T. Beiträge zur Schotteranalyse. Min. Petrog. Mitt. Schweiz. 1935, 15, 39-140.

29. Klein, G.D.; Pettijohn, F.J. Sedimentary rocks. Am. J. Sci. 1976, 276, 766. [CrossRef]

30. Krumbein, W.C. Measurement and Geological Significance of Shape and Roundness of Sedimentary Particles. J. Sediment. Res. 1941, 11, 64-72. [CrossRef]

31. Aschenbrenner, B.C. A new method of expressing particle sphericity. J. Sedim. Petr. 1956, 26, 15-31.

32. Sneed, E.D.; Folk, R.L. Pebbles in the Lower Colorado River, Texas a Study in Particle Morphogenesis. J. Geol. 1958, 66, 114-150. [CrossRef]

33. Smalley, I.J. The presentation of subjective shape and roundness data. Sedimentology 1967, 8, 35-38. [CrossRef]

34. Dobkins, J.E.; Folk, R.L. Shape Development On Tahiti-Nui. J. Sediment. Res. 1970, 40, 1167-1203.

35. Graham, D.; Midgley, N. Graphical representation of particle shape using triangular diagrams: An Excel spreadsheet method. Earth Surf. Process. Landf. 2000, 25, 1473-1477. [CrossRef]

36. Blott, S.; Pye, K. Particle shape: A review and new methods of characterization and classification. Sedimentology 2007, 55, 31-63. [CrossRef]

37. Novák-Szabó, T.; Domokos, G. A new classification system for pebble and crystal shapes based on static equilibrium points. Central Eur. Geol. 2010, 53, 1-19. [CrossRef]

38. Šikić, K. Overview of geological structure of the Medvednica Mt. In Geological Guide through Medvednica Mt; Šikić, K., Ed.; Croatian Geological Institute-Croatian Geological Society, INA-Oil Industry: Zagreb, Croatian, 1995; pp. 7-40. (In Croatian)

39. Tomljenović, B. Structural Characteristics of Medvednica and Samoborsko gorje Mountains. Ph.D. Thesis, University of Zagreb, Zagreb, Croatia, 2002.

40. Rudarsko-geološko-naftni zbornik. Rud. Geolo scaron; ko-Naft. Zb. 2020, 32, 1-13. 
41. Maricic, A.; Starčević, K.; Barudžija, U. Physical and mechanical properties of dolomites related to sedimentary and diagenetic features-case study of the Upper Triassic dolomites from Medvednica and Samobor Mts., NW Croatia. Rud. Geolo scaron; ko-Naft. Zb. 2018, 33, 33-44.

42. Sremac, J.; Kudrnovski, D.; Velić, J.; Bošnjak, M.; Velić, I. Statistical analyses of Late Cretaceous clastic deposits from Mali Potok Creek (Medvednica Mt., Northern Croatia). In Proceedings of the 2nd Croatian Congress on Geomathematics and Geological Terminology, Zagreb, Croatia, 6 October 2018; pp. 87-93.

43. Sremac, J.; Velić, J.; Bošnjak, M.; Velić, I.; Kudrnovski, D.; Troskot-Čorbić, T. Depositional Model, Pebble Provenance and Possible Reservoir Potential of Cretaceous Conglomerates: Example from the Southern Slope of Medvednica Mt. (Northern Croatia). Geosciences 2018, 8, 456. [CrossRef]

44. Jelić, T.; Kalogjera, A. Geological Map of the SE Europe. In Atlas of the World; Mozaik knjiga: Zagreb, Croatian, 2001. (In Croatian)

45. Ballivy, G.; Dayre, M. The mechanical behaviour of aggregates related to physicomechanical properties of rocks. Int. Assoc. Eng. Geol. Bull. 1984, 29, 339-342.

46. Teymen, A. Estimation of Los Angeles abrasion resistance of igneous rocks from mechanical aggregate properties. Bull. Int. Assoc. Eng. Geol. 2017, 78, 837-846. [CrossRef]

47. Tomašić, I.; Ženko, T.; Aljinović, S. Resistance of dolomite aggregates on percussive-wear load and freezing. Rud. Geolo scaron; ko-Naft. Zb. 1992, 4, 119-126. (In Croatian).

(C) 2020 by the authors. Licensee MDPI, Basel, Switzerland. This article is an open access article distributed under the terms and conditions of the Creative Commons Attribution (CC BY) license (http://creativecommons.org/licenses/by/4.0/). 